\title{
Education and articulation: Laclau and Mouffe's radical democracy in school
}

\author{
Itay Snir
}

The Open University of Israel and Minerva Humanities Center, Tel Aviv University, Tel Aviv, Israel

\begin{abstract}
This paper outlines a theory of radical democratic education by addressing a key concept in Laclau and Mouffe's Hegemony and Socialist Strategy: articulation. Through their concept of articulation, Laclau and Mouffe attempt to liberate Gramsci's theory of hegemony from Marxist economism, and adapt it to a political sphere inhabited by a plurality of struggles and agents none of which is predominant. However, while for Gramsci the political process of hegemony formation has an explicit educational dimension, Laclau and Mouffe ignore this dimension altogether. My discussion starts with elaborating the concept of articulation and analysing it in terms of three dimensions: performance, connection and transformation. I then address the role of education in Gramsci's politics, in which the figure of the intellectual is central, and argue that radical democratic education requires renouncing that figure. In the final section, I offer a theory of such education, in which both teacher and students articulate their political differences and identities.
\end{abstract}

\section{KEYWORDS}

Democratic education; articulation; intellectuals; Ernesto Laclau; Chantal Mouffe

\section{Introduction}

Democratic education, like democracy in general, seems to have fallen into a deep crisis in both theory and practice. The foundation upon which classical democracy is presumed to rest is torn by tensions between the principles of equality and individual rights, between the nation-state and indigenous and migrant cultures, between identities and differences. I believe that a way out of this conundrum may be found in Ernesto Laclau and Chantal Mouffe's 1985 Hegemony and Socialist Strategy (Laclau and Mouffe 1985, hereafter HSS). In this book, the authors develop a political theory without an ultimate foundation, which acknowledges the tension between democracy and liberalism as well as the constructedness and fluidity of every identity. However, the radical democratic theory articulated in this book has hardly affected educational discourse, and the few attempts by educational 
theorists to engage it focus on Laclau's or Mouffe's later works, thereby missing much of the complexity and radicalness of their coauthored book (Ruitenberg 2008; Biesta 2011; Szkudlarek 2011, 2013). In this paper I outline a theory of radical democratic education by addressing a key concept in Hegemony and Socialist Strategy: articulation.

Articulation usually means either a joint or juncture between bones, or the act of linguistic expression, putting something into words to make sense. Laclau and Mouffe join these two semantic fields together, and add a third, sociopolitical one: in their political theory articulation means 'any practice establishing a relation among elements such that their identity is modified as a result of the articulatory practice' (HSS, 105). That is to say, when individual or collective subjects engage in political articulation they do not form a coalition or aggregate in which each element retains its original identity, or a union which requires renunciation of former identities, but rather create a hegemonic front whereby the identity of each subject is reshaped. Through their concept of articulation, Laclau and Mouffe attempt to liberate Antonio Gramsci's theory of hegemony from Marxist economism, and adapt it to a political sphere inhabited by a plurality of struggles and agents none of which is predominant. However, while for Gramsci the political process of hegemony formation has an explicit educational dimension, Laclau and Mouffe ignore this dimension altogether - they fail to articulate it, so to speak.

My discussion starts with elaborating the concept of articulation and analyzing it in terms of three dimensions: performance, connection and transformation. I then address the role of education in Gramsci's politics, in which the figure of the intellectual is central, and argue that radical democratic education requires renouncing that figure. In the final section, I offer a theory of such education, in which both teacher and students articulate their political differences and identities.

\section{Articulation and hegemony}

Laclau and Mouffe understand democratic politics as 'collective action, directed towards struggling against inequalities and challenging relations of subordination' (HSS, 153). Starting from the French Revolution, the democratic-egalitarian principle of equality replaced the theological-political one, which had legitimized hierarchies by appealing to divine will, as 'the new matrix of the social imaginary' (HSS, 155). However, the fundamental opposition people/ancien régime, which was the dividing line along which demands for equality were organized at the time of the Revolution, soon turned out to be insufficient, for 'the people' disintegrated into multiple identities and demands which could not be satisfied by fighting the ancien régime. As a result, constructing the line dividing oppressors and oppressed became the primary political task (HSS, 151). 
Marxism was part of this democratic revolution, and its power in the second half of the nineteenth century derived from its ability to constitute a new frontier by bringing together various groups and demands for equality under the banner of class struggle. The impasse in which Marxism found itself in the twentieth century resulted above all from the decline of the proletariat's unifying power, followed by its inability to account for the plurality of new social movements - feminist, ethnic, environmental and others - which removed class struggle from its privileged position in democratic-egalitarian politics (HSS, 159). Laclau and Mouffe's radical democracy aimed at combining the principle of democratic equality with a pluralist one, in an attempt to rethink the conditions of joint political struggle while acknowledging an open, contingent variety of democratic political subjects whose interactions could not be determined in advance:

The rejection of privileged points of rupture and the confluence of struggles into a unified political space, and the acceptance, on the contrary, of the plurality and indeterminacy of the social, seem to us the two fundamental bases from which a new political imaginary can be constructed, radically libertarian and infinitely more ambitious in its objectives than that of the classic left. (HSS, 152)

The key to this political theory is found in Antonio Gramsci's concept of hegemony. ${ }^{1}$ In traditional Marxist thought, hegemony designates leadership by consent, namely domination enjoying popular legitimacy and requiring minimal use of violent coercion (Forgacs 2000, 137). But while Soviet Marxists like Lenin and Bukharin use this concept (in Russian: gegemonia) exclusively to describe the desirable relations between the proletariat and other groups it had to lead in the struggle against the bourgeoisie, in Gramsci's Prison Notebooks hegemony is not predetermined by the economic identities of the elements composing it. Gramsci insists that the nature of anti-capitalist hegemony should not be determined by the proletariat alone - other subordinated groups, such as peasants, have much to contribute to the form hegemony assumes (Gramsci 2000, 190-221). Hence, all the groups constituting hegemony - including the proletariat - influence and alter each other. Hegemony is not a relation between groups with given identities and interests, joining together in an alliance, but rather a complex process which reshapes all parties involved through dynamic interactions between ideas, traditions and practices (Mouffe 1979). It is a multidirectional process of generating a new common sense, through which the views and values of the group claiming leadership adjust to those of the other groups so as to appear not as particular interests but as expressions of the common good, of collective popular will (Femia 1981, 46-48).

Laclau and Mouffe embrace the contingency of political identities implied by Gramsci's politics of hegemony, but reject the 'inner essentialist core' of his thought (HSS, 69), namely his insistence that stable hegemony can be formed only in the context of class struggle. They employ the concept of articulation to explicate and radicalize the dynamics expressed by Gramscian hegemony, to make it the conceptual foundation for thinking of politics without foundation:'the concept of 
hegemony supposes a theoretical field dominated by the category of articulation' (HSS, 93; italics in the original). In what follows, I articulate the concept of articulation by distinguishing between three aspects, which are not consequent phases but rather simultaneous dimensions making up articulatory practice: performance, connection and transformation.

According to traditional political thought, including both Jacobin and Marxist versions of democratic politics, society exists as a totality determining the meaning and identity of each of the elements constituting it. Thus, every frontier is internal to the social whole, and the nature of struggles against inequality as well as the identity of the political subjects able to lead them can be determined in advance (HSS, 152). Laclau and Mouffe employ the concept of articulation to challenge this presupposition and reject the determinism it implies:

In order to place ourselves firmly within the field of articulation, we must begin by renouncing the conception of 'society' as founding totality of its partial processes ... There is no sutured space peculiar to 'society', since the social itself has no essence. (HSS, $95,96)^{2}$

Instead, social space is composed of a plurality of discourses each of which allows but partial stabilization of meanings around a temporary'nodal point' (HSS, 113). Hence, meanings and identities do not exist objectively, in a stable field of differences: they are constituted discursively in and through their articulations, realized only when performed by speaking and acting agents.

As discourses are unstable, mutable formations where utterances, gestures and objects are circulated (HSS, 105), Laclau and Mouffe write that'a discursive totality never exists in the form of a simply given and delimited positivity ... there is no social identity fully protected from a discursive exterior that deforms it and prevents it becoming fully sutured'(HSS, 110, 111; italics in the original). Accordingly, no performance is merely a repetition of a given pattern; all necessarily involve unpredictable interactions:'all identity is relational - even if the system of relations does not reach the point of being fixed as a stable system of differences' (HSS, 113). In other words, articulation always involves connections; to articulate is to articulate with. However, unlike the encounter of elements whose identities are positively determined by a given social structure, the articulating elements have a 'floating character' (ibid.) and therefore transform while performing and connecting, thereby changing existing discourses or creating new ones (Laclau 2014a).

Although not every articulation is necessarily political, the logic of articulation sheds new light on the way political demands and struggles operate, as well as on the formation of hegemonic fronts. Laclau and Mouffe explain that political hegemony can be formed when the performance of discursive practices and identities generates antagonism, namely when it expresses the performer's inability to be 'totally himself,' to have a close, objective identity within a stable system of differences: 'In the case of antagonism ... the presence of the "Other" prevents me from being totally myself' (HSS, 125; see also Laclau 2014b; Mouffe 1999, 38-53; Mouffe 2005, 101; Mouffe 2006, 127, 128). This is, for example, a woman's inability 
simply to be a female human without the relation to a man defining and positioning her social-discursive identity, constituting her as inferior and making gender relations antagonistic. Hegemony is formed when various antagonistic relations connect so as to concentrate around a single frontier: this is the case, to continue the example, when the demands of the 'woman' and the 'black' coalesce under the umbrella of class struggle and become articulated in its terms.

Such connection forms a relation of 'equivalence,' in which 'the identity of the object is split: on the one hand, it maintains its own "literal" sense; on the other, it symbolizes the contextual position for which it is a substitutable element' (HSS, 63). That is to say, in a chain of equivalence each demand for equality expresses not only itself but also something they all have in common (HSS, 128). Importantly, the common denominator has no positive identity, for the articulated demands originate in heterogeneous discourses; the nodal point around which hegemony consolidates is a 'floating signifier' (Laclau 1996, 36-46), a name that comes to signify, due to the process of articulation, not only a particular identity but also a universal shared by a plurality of demands and identities. This way, social space is divided into two opposing sides, 'us' and 'them' (Laclau 2006, 2007, 95) - as when the category of 'class' signifies in a given historical moment something shared by a variety of struggles - economic, feminist, racial, and others. Such a process clearly transforms the articulating elements, including the one whose name comes to signify the emerging hegemony; hence, hegemony itself is a fluid and dynamic collective subject, whose identity is constantly transforming.

\section{Education and the intellectual}

Political articulation has an obvious educational dimension: it involves learning, growing to understand each other and the development of identities into broader and more inclusive ones. Nevertheless, Laclau and Mouffe do not address this dimension, and barely touch upon educational issues in either their shared or individual works. This is especially surprising in light of the fact that in Gramsci, educational issues are explicit and crucial to the process of hegemony formation. A brief look at Gramsci's view of education will provide a clue as to the reason why Laclau and Mouffe avoided educational questions, and more importantly enable to develop an educational approach based on their concept of articulation.

The problem of education arises in Gramsci's thought due to the relative autonomy of consciousness, which is no simple reflection of the mode of production. Politics is accordingly not an epiphenomenon of economy but rather a continuous 'war of position' over the masses' consent and cooperation: this war takes place not in the battlefield or parliament, but rather in civil society and everyday life. It is waged over cultural and artistic productions, over understandings of traditions and religious beliefs, even over how words are understood - this is, then, a large-scale educational struggle over consciousness (Gramsci 2000, 225-230; Giroux 1999). The vanguard (or HQ) consists of the intellectuals, whose role is to educate ordinary 
people and generate consent to hegemonic ideas and values. Traditional intellectuals use their influence over the organization and distribution of knowledge and culture to make the worldview of the ruling class appear common-sensual, namely to facilitate public legitimacy for existing power relations. As a result of the work of such intellectuals, Gramsci writes, the common man

has formed views, convictions, discriminating criteria, and norms of behavior. Every supporter of a viewpoint that contrasts with his own, being intellectually superior, knows how to argue his reasons more than a common man can do; he is able to overwhelm him with logic, and so on. Should common man, therefore, change his convictions? ... Common man thinks that the many cannot go wrong, in contrast to what the opponent would have him believe. Even if he himself is, in truth, incapable of sustaining and articulating his own opinions as his opponent does, he is certain that there is in his group someone who knows how to do it, certainly even better than that particular opponent. In fact, he remembers having heard the reasons for his faith expounded widely and coherently, such that he has remained convinced. (quoted in Santucci 2010, 139, 140)

However, intellectuals also play a crucial role in the formation of counter hegemony. Challenging the ruling hegemony and creating an alternative are possible, according to Gramsci, because notwithstanding the efforts of traditional intellectuals, the ideological worldview of the masses is never a coherent whole. Thoughts and ideas are essentially connected to the lives of the people conceiving them, thereby reflecting the true nature of social reality. That is to say, although traditional intellectuals usually succeed in promoting the worldview of the ruling classes and making it appear self-evident, against this influence stands the practical everyday experience of the working classes, which also influences their common sense. Gramsci calls these authentic aspects of the workers' common sense good sense: 'this is the healthy nucleus that exists in "common sense", the part of it that can be called "good sense" and that deserves to be made more unitary and coherent' (Gramsci 2000, 329).

Yet, although good sense expresses the genuine interests of the masses, it is usually not formulated clearly and eloquently, and is often not even fully conscious:

[T]he active man-in-the-mass has a practical activity, but has no theoretical consciousness of his practical activity ... One might almost say that he has two theoretical consciousnesses (or one contradictory consciousness): one which is implicit in his activity and which in reality unites him with all his fellow-workers in the practical transformation of the real world; and one, superficially explicit or verbal, which he has inherited from the past and uncritically absorbed. (Gramsci 2000, 333)

That is to say, people may act in ways that contradict what they state or think, not being fully aware of the positions implicit in what they do. They may feel oppression on their flesh and even express discontent or rage, but are often unable to come up with a reflective account of the meaning and causes of their experiences (Femia 1981, 31). Gramsci insists that 'everyone is a philosopher,' namely able to think critically, but in the absence of proper conceptual tools he lacks the means to formulate the radical alternative embedded in his practical experience and turn it into genuine resistance (Gramsci 2000, 325). ${ }^{3}$ 
Intellectuals are therefore required to help workers attain a higher level of reflective self-consciousness, give linguistic form to their good sense and explicate it as part of their class struggle. These intellectuals are not 'traditional,' but 'organic', coming from amongst the oppressed and expressing their class interests. To be sure, the 'subjects of history,' the ultimate agents of political struggle, must be the working masses; but for this to happen, the intellectual must 'throw himself, too, into practical life, and become an organizer of the practical aspects of culture ... he must democratize himself' (quoted in Santucci 2010, 143). To be sure, intellectuals democratize not by somehow being elected, but by virtue of the joint process they undergo with the masses: a process in which they do not only teach but also learn from the experiences of the workers and shape the proletarian hegemonic front according to the latter's good sense (Mayo 1999). The work of organic intellectuals is therefore essentially educational, and as Michael Apple observes it is also the political task of contemporary democratic educators committed to 'interrupting the right': instead of rejecting the students' worldview, teachers have to be attentive to their experiences and cultures, select the good-sensical elements they contain, and reposition them within a progressive counter-hegemony (Apple 2006, 2009).

Gramsci's view is easily translated into Laclau and Mouffe's vocabulary, in which hegemony is generated by articulatory practice. In their terms, the aim of the intellectuals is to help the workers articulate good sense: perform it linguistically, connect it to class struggle, and transform it into a moment of the hegemonic front. Indeed, various scholars have attempted to extricate from Laclau and Mouffe's political theory educational insights aligned with Gramsci's conceptualization of the teacher as an organic intellectual (Lewis 2012). Claudia Ruitenberg (2010) argues, in this vein, that an important but neglected educational-political task is teaching to articulate. She takes up Simon Critchley's $(2013,7)$ claim regarding a deficit in political motivation due to the lack of ethical foundation to contemporary secular liberal democracy, and argues that 'in addition to an ethical deficit, an articulatory deficit plagues the contemporary political situation. Therefore, citizens should learn not only to perceive ethical injustice ... but also to form and articulate political demands' (Ruitenberg 2010, 373, italics in the original). That is to say, articulation is a complex political practice, and does not simply follow the understanding that political struggle is necessary. Professional help is needed to provide the relevant knowledge without which political education is incomplete:

If a person has no idea how to translate her or his ideas about a desirable social order into actions that aim to bring this social order about, then I would argue that we cannot call this person 'politically educated.' Indeed, having some knowledge of how to translate one's perceptions of injustice into actions that aim to lessen this injustice is part of what others have called 'political efficacy': the belief that one's actions can make a political difference. Political efficacy combines the sense of agency and the ability to articulate one's individual actions with those of others ... and it is an important part of citizenship education that takes the political aspects of citizenship seriously. (Ruitenberg 2010, 377, 378) 
The educator who teaches to articulate is akin to the Gramscian intellectual without whom political articulation and the construction of democratic hegemony are impossible (Rømer 2011).

However, I believe that Laclau and Mouffe's logic of articulation requires rejecting the figure of the intellectual, and the centrality of this figure in Gramsci's theory of education may even offer a possible explanation for their avoidance of educational questions. Organic and democratic as he may well be, the intellectual knows and teaches - he knows in advance the frontier dividing the social field into two antagonistic sides, and teaches the ways good sense should be articulated. This brings an element of necessity into the contingent logic of articulation, and closes off political possibilities instead of accepting their radical plurality. Laclau and Mouffe write that 'From the point of view of a hegemonic politics, then, the crucial limitation of the traditional left perspective is that it attempts to determine a priori agents of change, levels of effectiveness in the field of the social, and privileged points and moments of rupture' (HSS, 178, 179). Hence, 'there is no radical and plural democracy without renouncing the discourse of the universal and its implicit assumption of a privileged point of access to 'the truth' (HSS, 191, 192). This can easily be read as a rejection of the role Gramsci ascribes to intellectuals and of his theory of education altogether.

Although Laclau and Mouffe do not attack the Gramscian intellectual directly and hence, this explanation for their avoidance of educational questions remains speculative - consistent elaboration of radical democratic politics in the field of education faces the challenge of ridding itself of the figure of the intellectual, of he who knows in advance. In the remainder of the article, I offer such elaboration by stressing the importance of articulation to democratic education.

\section{Articulating radical democratic education}

While dominant contemporary approaches to democratic education aim at incorporating the differences between students into the national-civic identity (Callan 2004) or bridging over them by way of rational deliberation (Gutmann 1999), radical democracy opposes all forms of inequality and subordination, and therefore posits that the irreducible plurality of differences needs to be articulated so as to make inequalities visible. For democratic education to take place, students must perform their discursive identities: not only 'be themselves,' but rather actively engage the question, 'What does it mean to be me?' and reflect on and give linguistic form to their social positions and their complex relations with other social positions. Such reflection is not directed inwards, to some alleged positive essence, but rather outwards, or more precisely towards the relations with the outside which constitute and give meaning to the inside. To be sure, this reflection should not be taken to be either rational or irrational, for the very definition of rationality and irrationality is dependent upon the relevant discourse - articulation is performance 
and reshaping of experience itself, of the way one senses the world and makes sense of it.

Moreover, unlike the more conventional process of 'discovering oneself', the performative aspect of articulation must have a public dimension: the discursive identities and social relations need not only become more transparent to the articulating subject, but also appear as such to others - classmates, teachers, even parents - exposing to them new layers of social reality. Much like in Gramsci, this implies recognition that the students' identities and experiences are politically important not only due to their psychological significance to individuals' sense of agency and belonging, but also because they contain valuable truths regarding social reality and the numerous relations of oppression it harbors.

However, Laclau and Mouffe emphasize that not all relations of subordination appear as illegitimate oppression - inequality may be situated within a discourse in which it seems natural or justified (HSS, 153, 154). For such relations of subordination to become antagonistic, their articulation must connect them with discourses which will frame them as oppressive. Gender identity, for example, which often seems to reflect natural differences, may connect to the discourse of universal human rights so as to allow the subordination of women to men to emerge as a form of oppression and for a democratic demand for equality to arise.

Clearly the discourse of rights in this example does not replace the one in which the female student appears as a 'natural woman,' but rather interacts with it in a way that transforms them both: it is not only the student's views that change, but rather the way she perceives and experiences herself, her world and the relations between the two. In other words, she transforms her very identity - the meaning of being a woman (or man), in class or anywhere else, does not remain the same after being articulated with the discourse of rights - and obviously, the meaning of a universal right also changes once understood also in the context of gender. Thus, the question 'What does it mean to be me?' never gets a definitive answer and must be constantly asked, carrying on the practice of articulation. In this sense radical democratic education differs from multicultural education, for performing and explicating the differences are not intended to strengthen or'empower' them but to open them up for other discourses, allowing them to transform while connecting with each other - not, to be sure, in order to renounce traditional identities and compromise old demands, but rather to form chains of equivalences able to become a hegemonic front demanding radical transformation of existing power relations.

What is the teacher's role in radical democratic education? It seems that the obvious answer is that she is to provide the nodal point for democratic articulation, namely the discourse making available the concepts, meanings and practices that connect to each of the students' particular identities and transform them into democratic demands in the chain of equivalence forming a hegemonic front. Although this answer leaves open the exact nature of the democratic discourse articulated by the teacher and does not limit it to class struggle, such a teacher 
would nevertheless be a version of the Gramscian intellectual: she will know in advance the central frontier separating oppressors from oppressed, and her task would be to make sure all democratic demands are articulated around it. Her articulatory practice, in other words, will not be complete, as it will set a priori limits to the available connections and transformations.

To break away from the position of the intellectual, the teacher must not attempt to pass on skills or knowledge - not even that of radical democratic theory - but rather fully engage the practice of articulation. Rather than teaching how to articulate or attempting to influence articulation from the distant standpoint of the one who knows in advance, the radical democratic teacher is first and foremost another element - albeit a rather dominant one - in the field of differences undergoing articulation. For her, no less than for her students, the answer to the question 'What does it mean to be me?' is far from straightforward. She has to perform her views and social identity, connect to other views and identities, and of course transform just like her students. To be sure, the articulating teacher's subjective experience is secondary to the political effect she sets in motion. Rather than forcing a specific discourse on the various differences undergoing articulation, she allows the frontier to rise from the demands articulated by the students, from what is important to them according to the discourses constituting their identities.

Such a teacher invites students of different identities to speak, learn and evolve together, without assuming the existence of a privileged discourse or an ultimate social identity all would have to assume. She acknowledges that everyone's life experiences provide them with knowledge and critical insights into oppressive social relations, and consequently the ability as well as the need for each to both teach and learn from all the others. Although the generational gap between teacher and students does not entirely disappear, their subject positions are being deconstructed and rearticulated within a new democratic educational discourse. At the same time, the students as well as the teacher become full political subjects, in line with the Gramscian trend, endorsed by Laclau and Mouffe, of extending political subjectivity to hitherto excluded social agents.

However, the democratic teacher's responsibility is not limited to providing the conditions and encouraging the students to engage in articulation, and she cannot remain indifferent to the specific nature articulations assume. Laclau and Mouffe make clear that there is nothing necessary in the ways different elements articulate, and no guarantee a demand for equality would be articulated with other democratic demands to form a democratic hegemony (HSS, 169). It certainly may, and often is, articulated with nationalist or neoliberal discourses in which some demands for equality come at the expense of others, and generate antagonism with other oppressed identities:

The democratic revolution is simply the terrain upon which there operates a logic of displacement supported by an egalitarian imaginary, but that it does not predetermine the direction in which this imaginary will operate ... [T] he discursive compass of the democratic revolution opens the way for political logics as diverse as right-wing populism and 
totalitarianism on the one hand, and a radical democracy on the other. (HSS, 168; italics

in the original; see also Mouffe 2005, 3)

For the direction indicated by the discursive compass to be that of democratic hegemony, the logic of equality must be accompanied with a pluralist logic, namely recognition of the equal right of different groups to demand equality, through an articulation creating equivalence between them without the one suppressing the other (Smith 1998, 6-41).

Hence, although the radical democratic teacher does not provide the articulating discourse and does not draw the frontier along which the struggle against inequalities consolidates, she is nevertheless responsible to do all within her power to direct the articulations - to articulate the principles of equality and pluralism in tandem so as to encourage the students to form the chains of equivalences accordingly. This responsibility concerns the democratic teacher not because she is a teacher but because she is democratic. Equally, it concerns every student committed to democracy. In any event, giving direction to articulation is not the same as providing it with content, and the democratic teacher is not pushed back to the position of the intellectual. Relying on the generational and structural differences between teacher and students to impose a specific content is not only unethical - bringing radical democratic education too close to indoctrination - but also runs against the political core of such democracy, which combines equality with pluralism. Therefore, the teacher must not introduce philosophical or political theories to the students, but rather articulate the views and practices they bring to class. That is to say, various discourses can provide the democratic nodal point, and democracy can take on many forms within the democratic direction. The teacher should show the students where a certain path they take might lead, expose the inequalities resulting from some articulations of demands for equality, and offer alternative, more pluralist routes. To push Laclau and Mouffe's metaphor a bit further, the teacher must offer a compass and a roadmap, not assume the role of navigator. Her role is negative in nature: to guard against undemocratic articulations without committing in advance to any specific nature of the democratic struggle. If she assumes a positive role, if she attempts to impose democracy from above, she undermines democracy itself; the egalitarian principle at the heart of democracy demands it to be articulated from the bottom up - from the students and not from an intellectual teacher. Nothing guarantees the success of democratic articulations in bringing about an egalitarian and pluralist hegemonic power, but setting a priori limits to political contingency compromises the radical nature of Laclau and Mouffe's democracy.

\section{Conclusion}

Engaging in radical democratic politics in school may seem problematic compared to other forms of political education, as it involves generating antagonisms and forming hegemonic fronts dividing the social space into' 'us' and 'them.'Does radical 
democratic education mean creating antagonisms between students in class? Does it aim at splitting the class into rival parties? I believe that understanding the role of articulation in radical democracy entails negative answers. Articulation is not a means to an end in the form of political struggle, for it is already itself political: by performing, connecting and transforming their identities and demands the students act politically, and if the chain of equivalence they form adheres to the principle of equality, their politics is democratic. This is exactly what Gramsci calls 'war of position': an essential part of political struggle that does not involve outright confrontation. Political confrontation may indeed take place in school - for no place is an island free of oppression and immune to struggles against it - but this is not a necessary outcome of radical democratic education. Articulation is a longterm, ongoing process which brings education and politics together, and does not stop at the school's doorstep. Placing articulation at the center means bringing to the fore of democratic education practices of self-expression and collaboration. It means articulating - performing, connecting and transforming - education and democracy themselves.

\section{Notes}

1. Gramsci did not invent this concept, and neither did his Marxist predecessors. As Peter Ives $(2004,63)$ notes, in ancient Greek hegemon means 'leader,' and the word has traditionally been used to designate a type of influence which is not total domination but rather a friendly albeit unequal alliance, in which the subordinated maintains a degree of autonomy (such was Athens' influence over neighboring city-states).

2. Laclau (1990, 89-93) distinguished between 'society' as a closed system and 'the social' as an open contingent formation.

3. This view is part of the backbone of Marxist tradition. In Pedagogy of the Oppressed, Freire $(1996,34)$ quotes Lukács who says that the revolutionary'must, to use the words of Marx, explain to the masses their own actions.'

\section{Disclosure statement}

No potential conflict of interest was reported by the author.

\section{ORCID}

Itay Snir (iD) http://orcid.org/0000-0003-4386-9251

\section{References}

Apple, M. W. 2006. Educating the Right Way: Markets, Standards, God, and Inequality. London: Routledge.

Apple, M. W. 2009. "Some Ideas on Interrupting the Right: On Doing Critical Educational Work in Conservative times." Education, Citizenship and Social Justice 4 (2): 87-101. 
Biesta, G. 2011. "The Ignorant Citizen: Mouffe, Rancière, and the Subject of Democratic Education." Studies in Philosophy and Education 30 (2): 141-153.

Callan, E. 2004. Creating Citizens: Political Education and Liberal Democracy. Oxford: Oxford University Press.

Critchley, S. 2013. Infinitely Demanding: Ethics of Commitment, Politics of Resistance. London:Verso.

Femia, J. V. 1981. Gramsci's Political Thought: Hegemony, Consciousness and the Revolutionary Process. Oxford: Clarendon Press.

Forgacs, D. 2000. "Introduction." In The Antonio Gramsci Reader, edited by D. Forgacs, 135-137. New York: NYU Press.

Freire, P. 1996. Pedagogy of the Oppressed. New York: Penguin.

Giroux, H. A. 1999. "Rethinking Cultural Politics and Radical Pedagogy in the Work of Antonio Gramsci." Educational Theory 49 (1): 1-19.

Gramsci, A. 2000. The Gramsci Reader. Edited by D. Forgacs. New York: NYU Press.

Gutmann, A. 1999. Democratic Education. Princeton, NJ: Princeton University Press.

Ives, P. 2004. Language and Hegemony in Gramsci. London: Pluto Press.

Laclau, E. 1990. New Reflections on the Revolution of Our Time. London: Verso.

Laclau, E. 1996. “Why Do Empty Signifiers Matter in Politics." Emancipation(s): 36-46. London: Verso.

Laclau, E. 2006. "Why Constructing a People is the Main Task of Radical Politics." Critical Inquiry 32 (4): 646-680.

Laclau, E. 2007. On Populist Reason. London: Verso.

Laclau, E. 2014a. "Articulation and the Limits of Metaphor." In The Rhetorical Foundations of Society, 53-78. London: Verso.

Laclau, E. 2014b. "Antagonism, Subjectivity and Politics." In The Rhetorical Foundations of Society, 101-125. London: Verso.

Laclau, E., and C. Mouffe. 1985. Hegemony and Socialist Strategy. New York: Verso.

Lewis, T. E. 2012."Mapping the Constellations of Educational Marxism(s)."Educational Philosophy and Theory 44 (1): 98-114.

Mayo, P. 1999. Gramsci, Freire and Adult Education: Possibilities for Transformative Action. London: Zed Books.

Mouffe, C. 1979. "Hegemony and Ideology in Gramsci." In Gramsci and Marxist Theory, edited by C. Mouffe, 168-204. London: Routledge \& Kegan Paul.

Mouffe, C. 1999. "Carl Schmitt and the Paradox of Liberal Democracy." In The Challenge of Carl Schmitt, edited by C. Mouffe, 38-53. London: Verso.

Mouffe, C. 2005. The Democratic Paradox. London: Verso.

Mouffe, C. 2006. The Return of the Political. London: Verso.

Rømer, T. A. 2011. "Postmodern Education and the Question of Power." Educational Philosophy and Theory 43 (7): 755-772.

Ruitenberg, C. W. 2008. "Educating Political Adversaries: Chantal Mouffe and Radical Democratic Citizenship Education." Studies in Philosophy and Education 28 (3): 269-281.

Ruitenberg, C. W. 2010. "Learning to Articulate: From Ethical Motivation to Political Demands." Philosophy of Education 2010: 372-380.

Santucci, A. 2010. Antonio Gramsci. New York: Monthly Review Press.

Smith, A. M. 1998. Laclau and Mouffe: The Radical Democratic Imaginary. London: Routledge.

Szkudlarek, T. 2011. "Semiotics and Identity: Politics and Education." Studies in Philosophy and Education 30 (2): 113-125.

Szkudlarek, T. 2013. "Identity and Normativity: Politics and Education." In Education and the Political, edited by Tomasz Szkudlarek, 61-74. Rotterdam: Sense Publishers. 